\title{
HYPOZETES ANDREII (ACARI, ORIBATIDA, TEGORIBATIDAE), A NEW SPECIES OF ORIBATID MITES FROM SOUTH AFRICA
}

\section{Sergey G. Ermilov ${ }^{1 *}$, Elizabeth Hugo-Coetzee ${ }^{2,3}$, Alexander A. Khaustov ${ }^{1}$ and Jenő Kontschán ${ }^{4}$}

\author{
${ }^{1} \mathrm{X}$-BIO Institute, Tyumen State University, Tyumen, Russia \\ ${ }^{2}$ National Museum, Bloemfontein, South Africa \\ ${ }^{3}$ University of the Free State, Bloemfontein, South Africa \\ ${ }^{4}$ Plant Protection Institute, Centre for Agricultural Research, Budapest, Hungary \\ *corresponding author; e-mail: ermilovacari@yandex.ru
}

\begin{abstract}
A new oribatid mite species of the genus Hypozetes (Oribatida, Tegoribatidae) is described from soil in South Africa. Hypozetes andreii sp.n. differs from all other representatives of the genus by the presence of heavily and densely porose body surface. Distribution data of the new species are presented.
\end{abstract}

KEY WORDS: Tegoribatid mites, systematics, morphology, Ethiopian region.

DOI: 10.21684/0132-8077-2019-27-2-183-192

\section{INTRODUCTION}

This work, being a part of our study of the oribatid mite fauna (Acari, Oribatida) of South Africa (e.g., Ermilov et al. 2017, 2018, 2019; Bayartogtokh et al. 2018; Ermilov and HugoCoetzee 2019; Niedbała et al. 2019), is based on material collected from the soil in the Franklin Game Reserve during an expedition conducted in October 2018. In the course of a taxonomic identification, we found one new species belonging to the genus Hypozetes Balogh, 1959 (Tegoribatidae). The main goal of the paper is to describe and illustrate this new species, which was named Hypozetes andreii sp.n.

Hypozetes was proposed by Balogh (1959) with Hypozetes imitator Balogh, 1959 as type species. The genus comprises nine species and one subspecies, which are distributed in the Tropical and Subtropical regions (Subías 2004, updated 2019). The generic diagnostic traits were listed by Balogh (1959), Balogh and Balogh (1992) and BehanPelletier (2001). The systematic placement, phylogenetic relationships and morphological features of Hypozetes are presented by Behan-Pelletier (2001). An identification key to many species is given in Mahunka (1987).

Earlier, the representatives of Hypozetes were not registered in South Africa; hence, the genus is recorded in this country for the first time.

\section{MATERIALS AND METHODS}

The specimens were mounted in lactic acid on temporary cavity slides for measurement and illustration. Body length was measured in lateral view from the tip of the rostrum to the posterior edge of the notogaster. Notogastral width refers to the maximum width of the ventral plate in ventral view. All body measurements are presented in micrometers $(\mu \mathrm{m})$. Formulas for leg setation are given in parentheses according to the sequence trochanter-femur-genu-tibia-tarsus (famulus included). Formulas for leg solenidia are given in square brackets according to the sequence genutibia-tarsus.

Drawings were made with a camera lucida using a Leica transmission light microscope Leica DM 2500. Images were obtained with an AxioCam ICc3 camera using a Carl Zeiss transmission light microscope Axio Lab.A1. SEM micrographs were made with the aid of a JEOL JSM-6510LV SEM microscope.

Morphological terminology used in this paper follows that of F. Grandjean: see Travé and Vachon (1975) for references, Norton (1977) for leg setal nomenclature and Norton and Behan-Pelletier (2009) for overview.

The following abbreviations are used: lamlamella; $A l$-sublamellar porose area; $t u$ - tutorium; ro, le, in, $b s$ - rostral, lamellar, interlamellar and bothridial setae, respectively; $b o$ - bothridium; $D$-dorsophragma; $P$-pleurophragma; len-lenticulus; $c, d a, d m, d p, l a, l m, l p, h, p-$ notogastral setae; $S a, S 1, S 2, S 3$-notogastral sacculi; $i a, i m$, ip - notogastral lyrifissures; glaopisthonotal gland opening; $a, m, h$-subcapitular setae; or - adoral seta; $d, l, v, c m, a c m, u l, s u l, v t$, lt - palp setae; $\omega$ - palp and leg solenidion; asaxillary saccule; cha, chb-cheliceral setae; $\mathrm{Tg}$ —Trägårdh's organ; $\mathrm{Am}, \mathrm{Ah}$ - humeral porose 


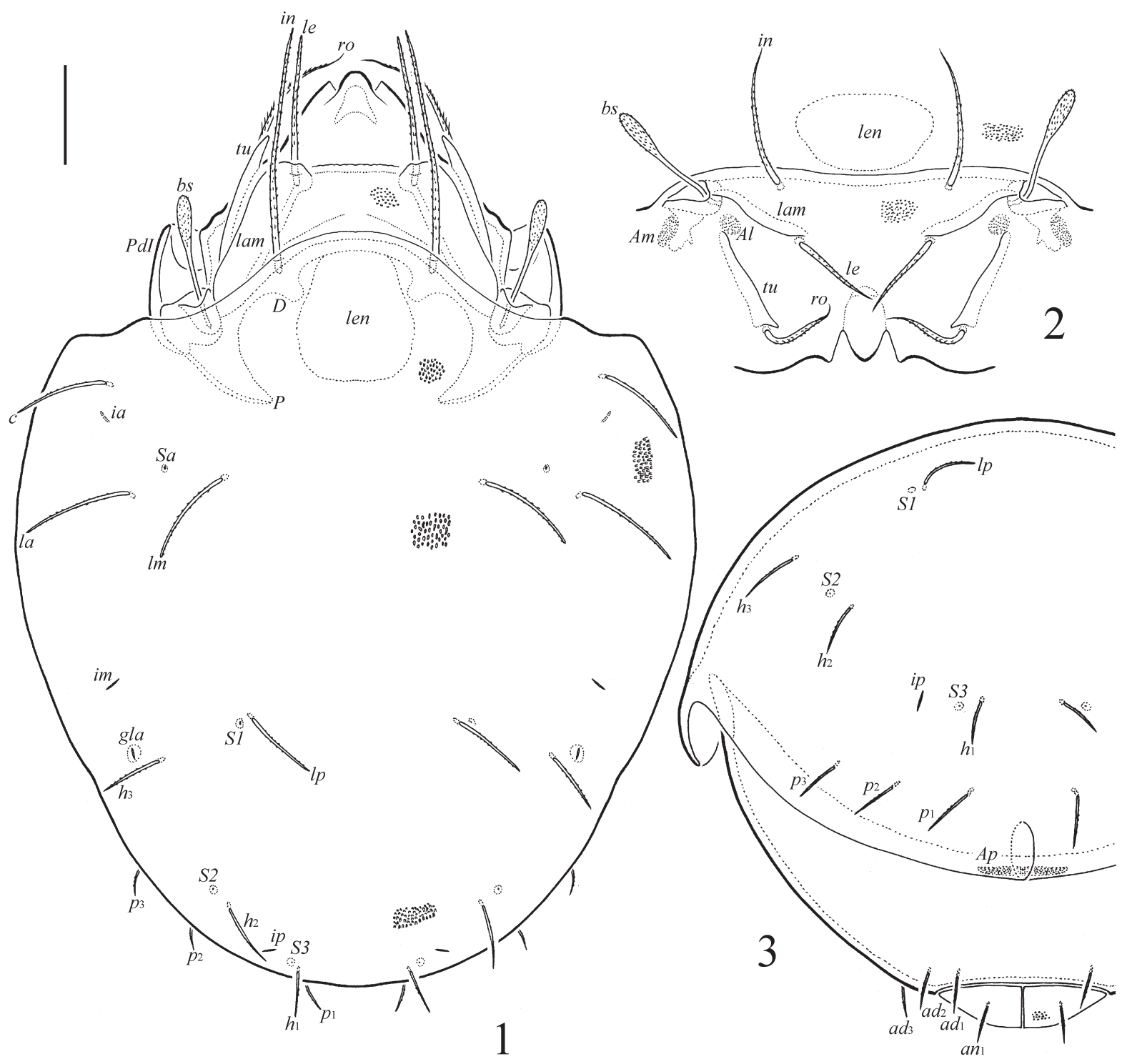

Figs. 1-3. Hypozetes andreii sp.n., adult: 1-dorsal view (not shown: legs); 2-frontal view; 3-posterior view. Scale bar $=50 \mu \mathrm{m}$.

areas; $P d I, P d I I$ - pedotecta I and II, respectively; $1 a, 1 b, 1 c, 2 a, 3 a, 3 b, 3 c, 4 a, 4 b$-epimeral setae; cus-custodium; dis-discidium; $c p$-circumpedal carina; $g$, ag, an, ad-genital, aggenital, anal and adanal setae, respectively; iad-adanal lyrifissure; $A P$ - anal plate; $A p$ - postanal porose area; $p o$ - preanal organ; $\mathrm{Tr}, \mathrm{Fe}, \mathrm{Ge}, \mathrm{Ti}, \mathrm{Ta}$-leg trochanter, femur, genu, tibia and tarsus, respectively; $p a$-leg porose area; $\sigma, \varphi$-leg solenidia; $\varepsilon$-leg famulus; $f t$ "-leg seta.

\section{SYSTEMATICS}

Superfamily Achipterioidea

Family Tegoribatidae

Genus Hypozetes Balogh, 1959

Type species Hypozetes imitator Balogh, 1959

\section{Hypozetes andreii Ermilov, Hugo-Coetzee, Khaustov et Kontschán sp. $n$.}

(Figs. 1-24)

Diagnosis. Body size: 415-464 × 265-315. Body surface heavily and densely porose. Rostrum tripartite, median part rounded, lateral parts triangular. Prodorsal setae long, setiform, barbed. Bothridial setae clavate, barbed. Sublamellar, humeral and postanal porose areas present. Posterior notogastral margin divided and overlapping medially. Lenticulus distinct. Notogastral setae of medium size, setiform, rigid, barbed. Four pair of notogastral sacculi developed. Genal teeth fused with prodorsal surface. Epimeral and anogenital setae short, setiform, barbed. Leg genua I and II 


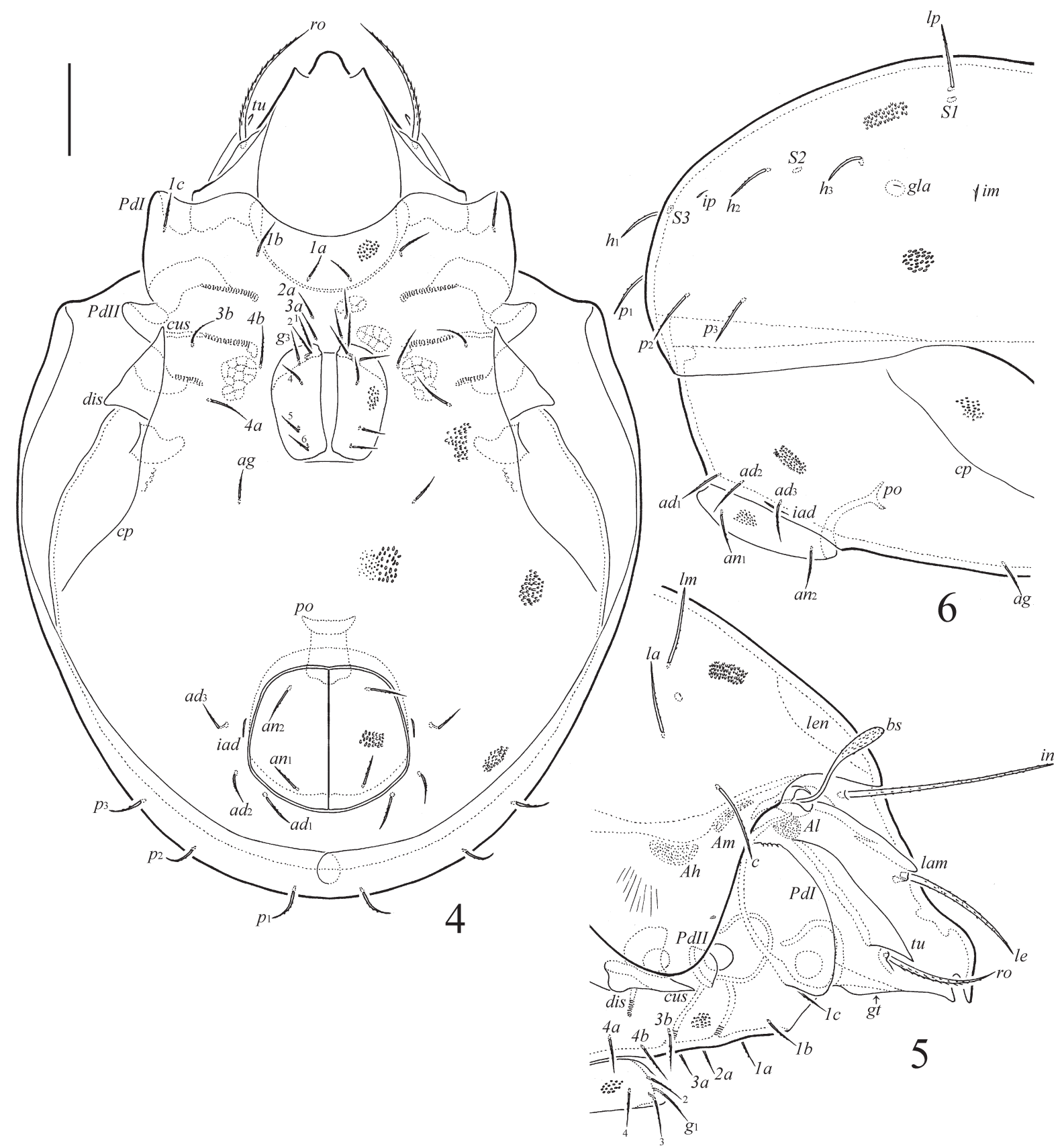

Figs. 4-6. Hypozetes andreii sp.n., adult: 4—ventral view (not shown: gnathosoma and legs); 5-anterior part of body, lateral view (not shown: gnathosoma and legs); 6 - posterior part of body, lateral view. Scale bar=50 $\mu \mathrm{m}$.

with triangular anteroventral process. Seta $l$ " on tibiae I, II and genua I, II, as well as seta $l^{\prime}$ on tibiae III, IV and genua III, IV thick.

Description. Measurements. Body length: 415 (holotype, male), 415-464 (six paratypes, one female and five males); notogaster width: 265 (holotype), 265-315 (six paratypes).

Integument (Figs. 19-24). Body color light brown to brown. Body surface, including subcapitular mentum as well as genital and anal plates, heavily and densely porose, distinctly visible even under low magnification (Figs. 21-23) under light microscope (poorly visible in SEM micrographs). Pores with minute openings (diameters up to 2) and small, slightly curved channels. Antiaxial sides of all leg femora and trochanters III, IV slightly striate.

Prodorsum (Figs. 1, 2, 5, 14, 16, 18, 19). Rostrum tripartite, with median rounded part, two lateral deep incisions and two lateral triangular parts. Lamellae $1 / 2$ of the length of prodorsum, with short, rounded lamellar cusps. Sometimes transverse ridge developed anteriorly to lamellae. Rostral setae 


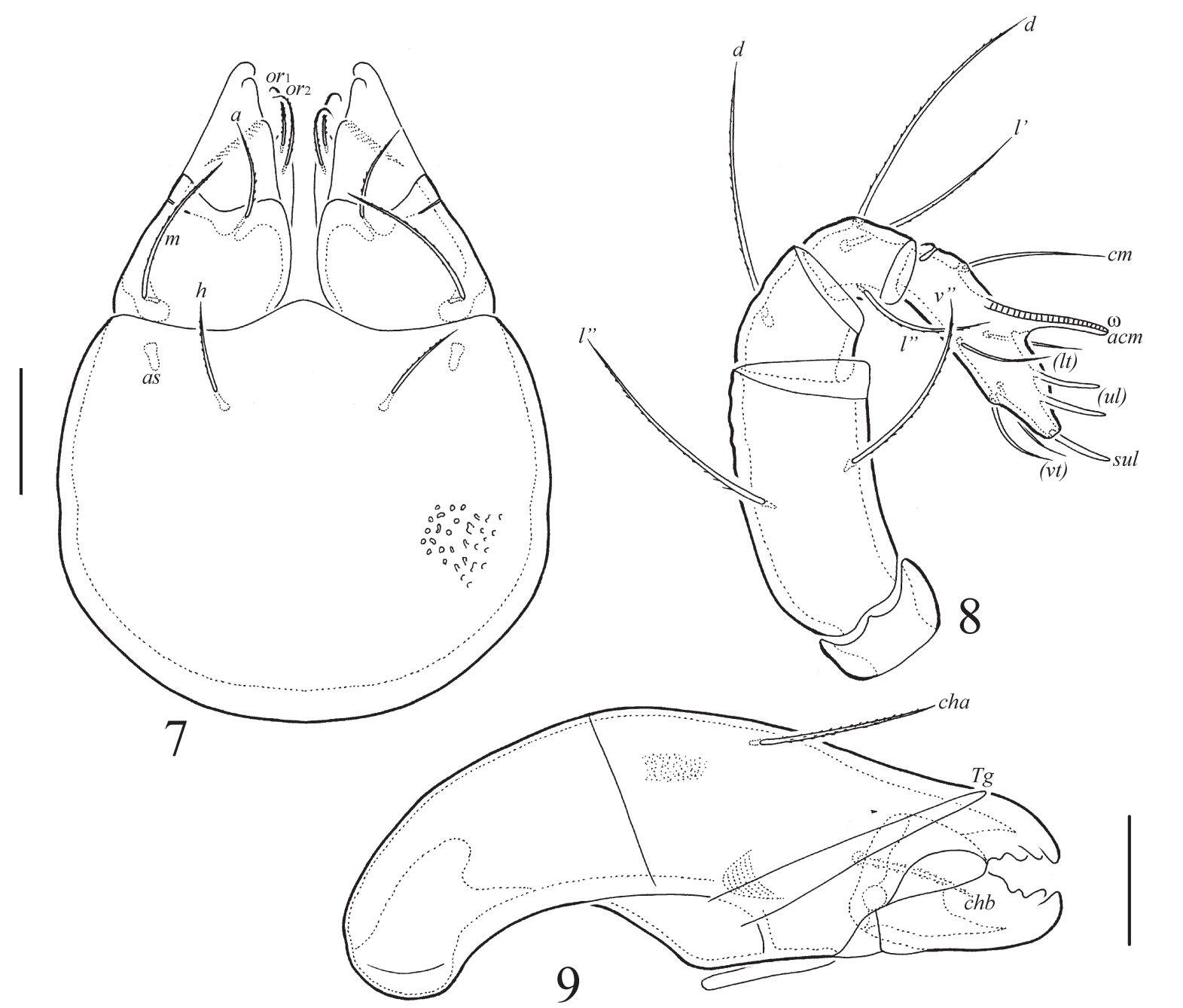

Figs. 7-9. Hypozetes andreii sp.n., adult: 7—-subcapitulum, ventral view; 8-palp, right, antiaxial view; 9-chelicera, left, paraxial view. Scale bars $=20 \mu \mathrm{m}$.

(73-82) setiform, barbed, directed anteromedially, located on lateral sides of prodorsum, close to tutorial cusps. Lamellar (73-82) and interlamellar (118-123) setae setiform, rigid, barbed; le inserted on prodorsal surface under lamellar cusps. Bothridial setae (65-69) clavate, barbed, with long stalk and long, elongate oval head. Exobothridial setae and their alveoli absent. Tutoria longer than lamellae, their cusps triangular. Sublamellar porose areas developed, poorly visible, located between bothridia and posterior part of tutoria. Dorsophragmata and pleurophragmata poorly visible. Dorsosejugal porose areas not evident.

Notogaster (Figs. 1-6, 14, 16-18, 21, 22). Anterior margin convex medially, covering insertions of interlamellar setae. Posterior margin divided and overlapping medially. Posterior notogastral tectum present. Pteromorphs triangular, broadly rounded. Lenticulus distinct, light. Ten pairs of setiform, rigid, barbed notogastral setae, $c, l a, l m$ and $l p$ (41-49) longer than others (28-32). Four pairs of sacculi with minute openings and drop-like chambers. Circumgastric sigillar band and lyrifissures $i h$, ips not evident. Opisthonotal gland openings and lyrifissures $i a$, im, ip poorly visible.

Gnathosoma (Figs. 7-9, 15). Subcapitulum longer than wide $(106-110 \times 82-86)$. Subcapitular setae setiform, barbed, $m(28-32)$ longer and thicker than $a(18-20)$ and $h(18-20)$. Two pairs of adoral setae (14-16) setiform, barbed. Palps (length 73-77) with typical setation 0-2-1-3$9(+\omega)$. Solenidion of palptarsi attached to setae acm mediodistally. Postpalpal setae (6) spiniform, smooth. Axillary sacculi distinct, elongated. Chelicerae (length 118-123) with two setiform, barbed setae, cha (32-36) longer than chb (2428). Trägårdh's organ of chelicerae elongate triangular. 
Hypozetes andreii from South Africa

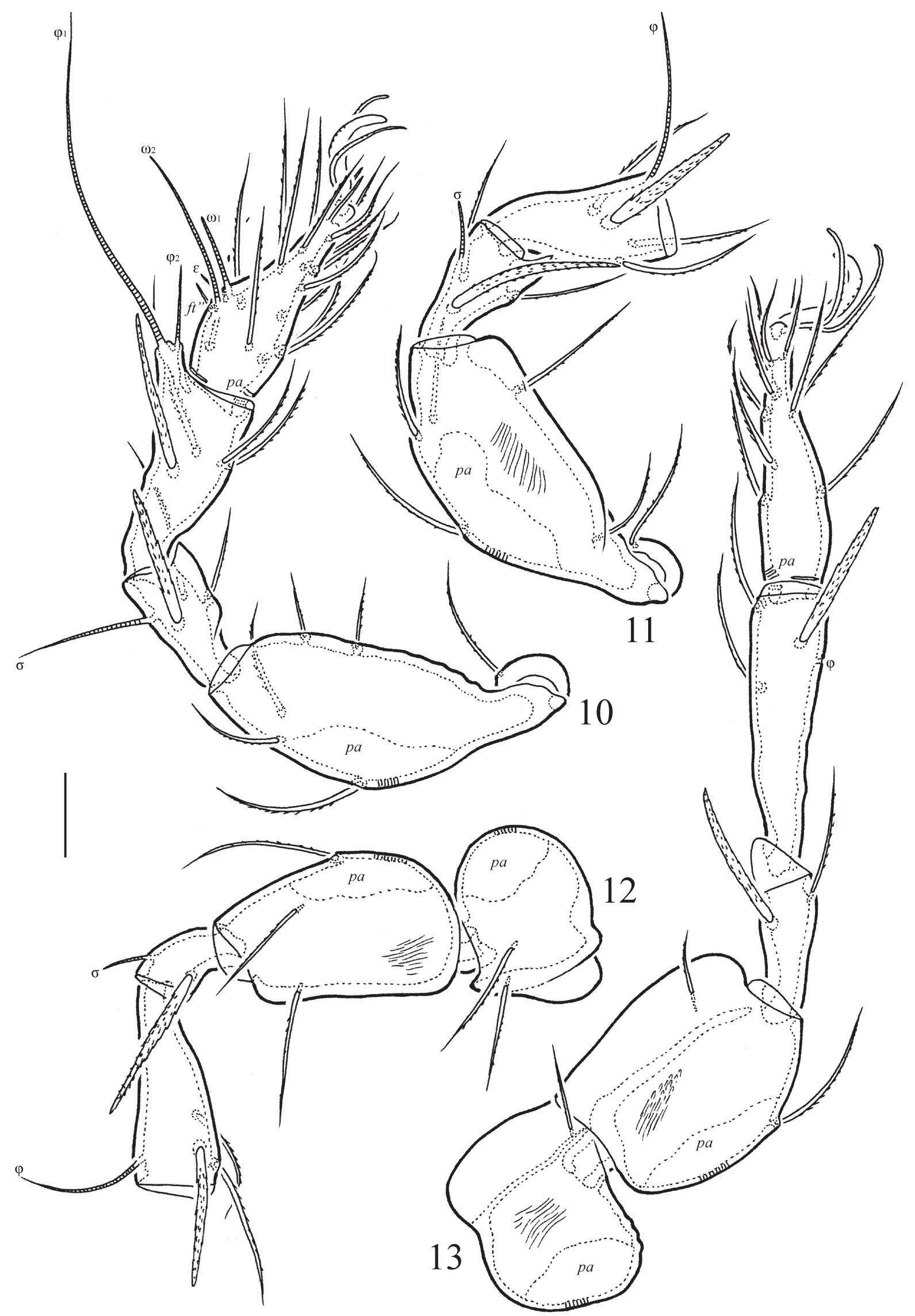

Figs. 10-13. Hypozetes andreii sp. n., adult: 10—leg I, right, antiaxial view; 11—leg II, without tarsus, right, antiaxial view; 12 - leg III, without tarsus, right, antiaxial view; 13 - leg IV, left, antiaxial view. Scale bar=20 $\mu \mathrm{m}$. 


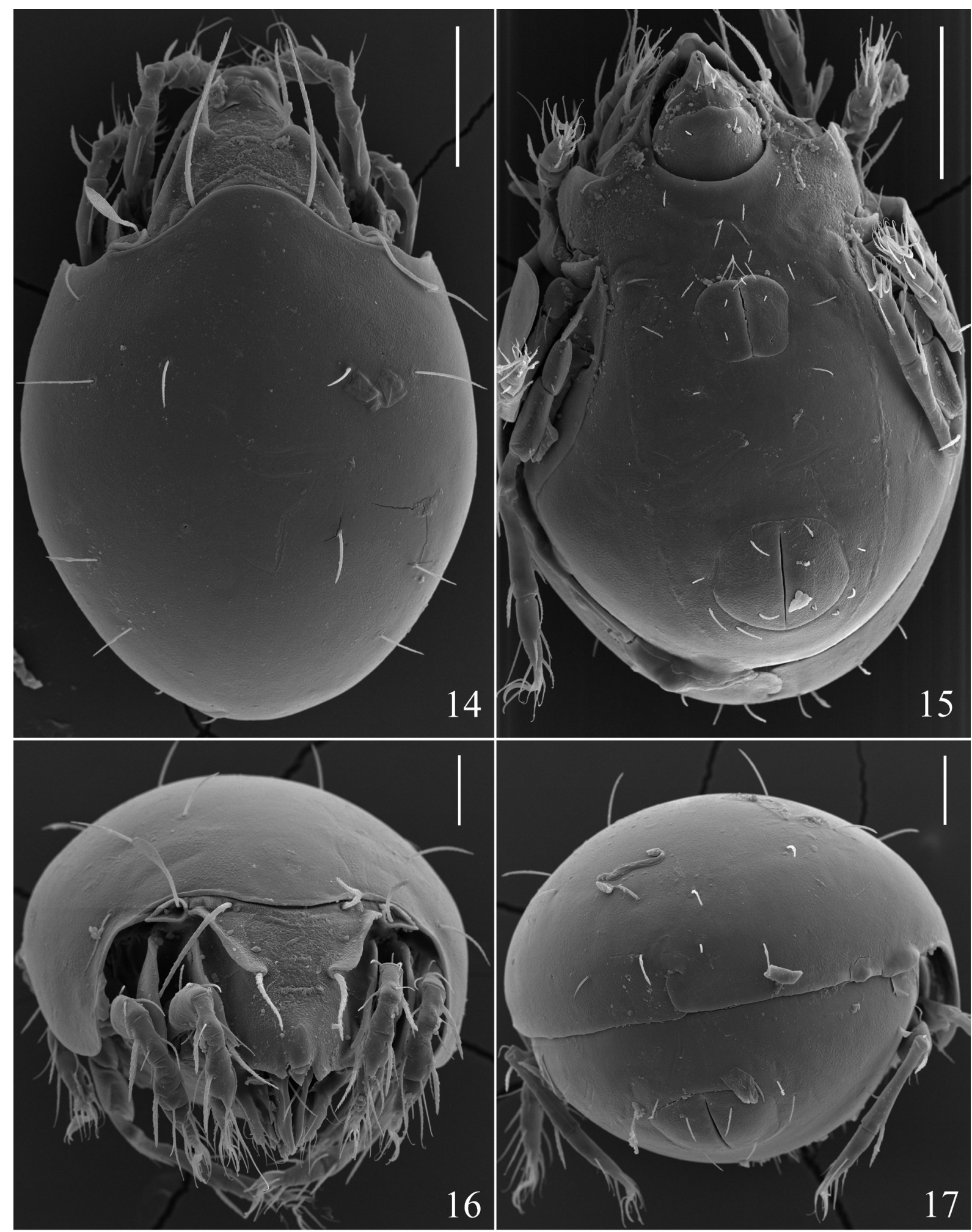

Figs. 14-17. Hypozetes andreii sp. n., adult, SEM micrographs: 14 - dorsal view; 15-ventral view; 16-frontal view; 17 - posterior view. Scale bars $=100 \mu \mathrm{m}(14,15), 50 \mu \mathrm{m}(16,17)$.

Epimeral and lateral podosomal regions (Figs. 4, 5, 15). Genal teeth triangular, indistinctly bordered, fused with prodorsal surface. Humeral porose areas $A m$ and $A h$ poorly visible, oval. Custodia with triangular, strong tips, reaching level of pedotecta II. Discidia triangular. Circumpedal ca- rinae distinct. Epimeral setal formula: 3-1-2-2. Epimeral setae setiform, thin, barbed, $1 a, 2 a$ and $3 a$ (16-20) shorter than others (20-24).

Anogenital region (Figs. 3-6, 15, 17). Six pairs of genital $\left(g_{1}-g_{3}, 20-24 ; g_{4}-g_{6}, 16-20\right)$, one pair of aggenital (20-24), two pairs of anal (20-24) and 

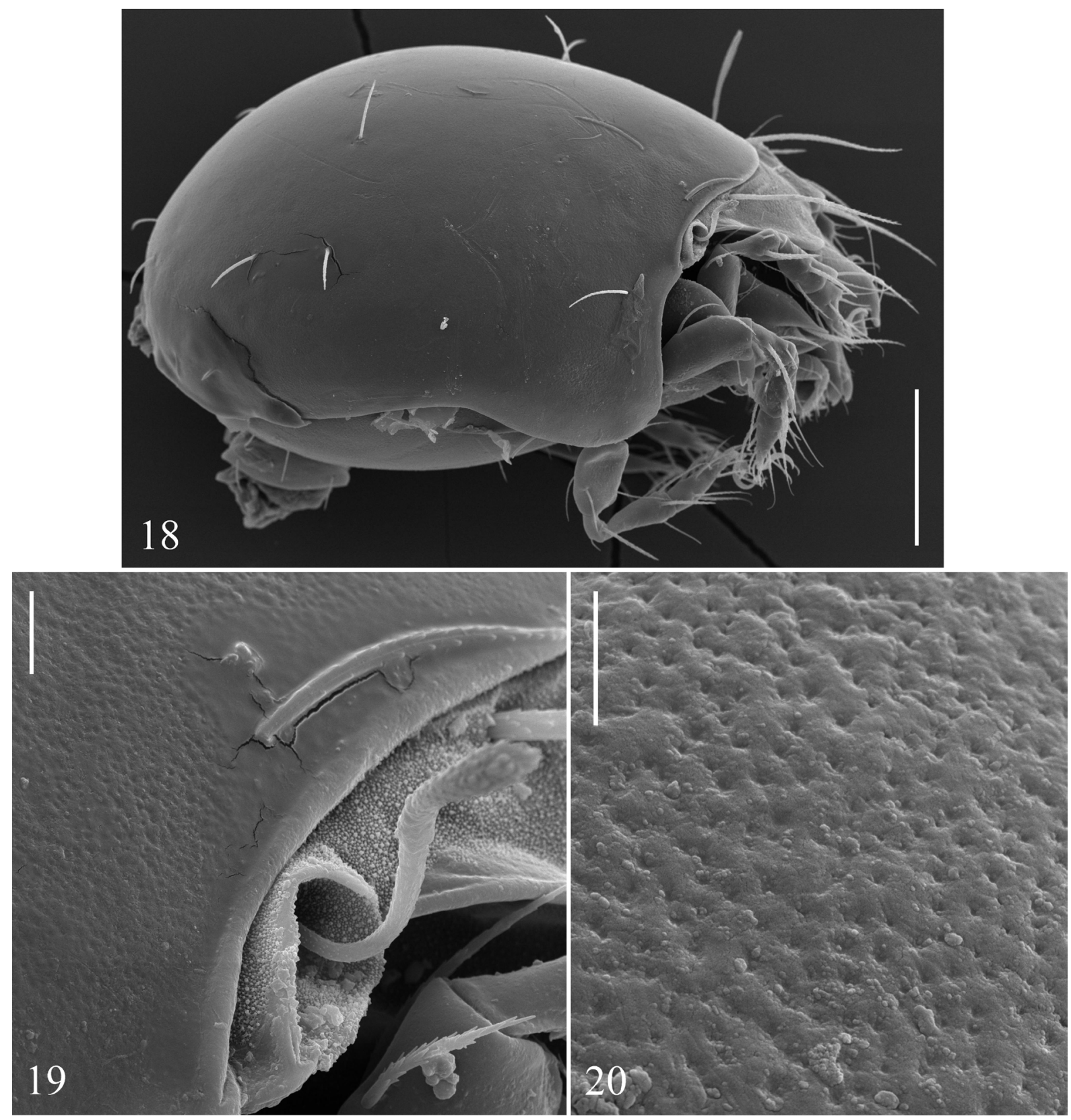

Figs. 18-20. Hypozetes andreii sp. n., adult, SEM micrographs: 18-lateral view; 19-bothridial seta, bothridial opening, humeral surface of notogaster, lateral view; 20 - heavily porose surface of notogaster. Scale bars $=100 \mu \mathrm{m}(18), 10 \mu \mathrm{m}$ (19), $5 \mu \mathrm{m}(20)$.

two pairs of adanal (20-24) setae setiform, thin, barbed. Adanal lyrifissures located close and parallel to anal aperture. Preanal organ elongate vaselike. Postanal porose area elongate oval.

Legs (Figs 10-13). Tridactylous, median claw distinctly thicker than laterals, all claws slightly barbed dorsally. Tibia I with anterodorsal apophysis. Genua I and II with triangular anteroventral process. Dorsoparaxial porose areas on femora IIV and on trochanters III, IV distinctly visible. Posteroventral porose areas on tarsi small. Anteroventral porose areas on tibiae absent. Formulas of leg setation and solenidia: I (1-5-3-4-19) [1-2-2], II (1-5-3-4-15) [1-1-2], III (2-3-1-3-15) [1-1$0]$, IV (1-2-2-3-12) [0-1-0]; homology of setae and solenidia indicated in Table 1. Solenidion $\varphi$ on tibiae IV reduced to vestigial alveoli (visible in dissected specimens). Famulus and seta $f t$ " of tarsi I short, stick-like. Seta $l$ " on tibiae I, II and genua I, II, as well as seta $l$ ' on tibiae III, IV and genua III, IV thick.

Material examined. Holotype (male) and four paratypes (one female and three males): South Africa, Bloemfontein, Franklin Game Reserve on 


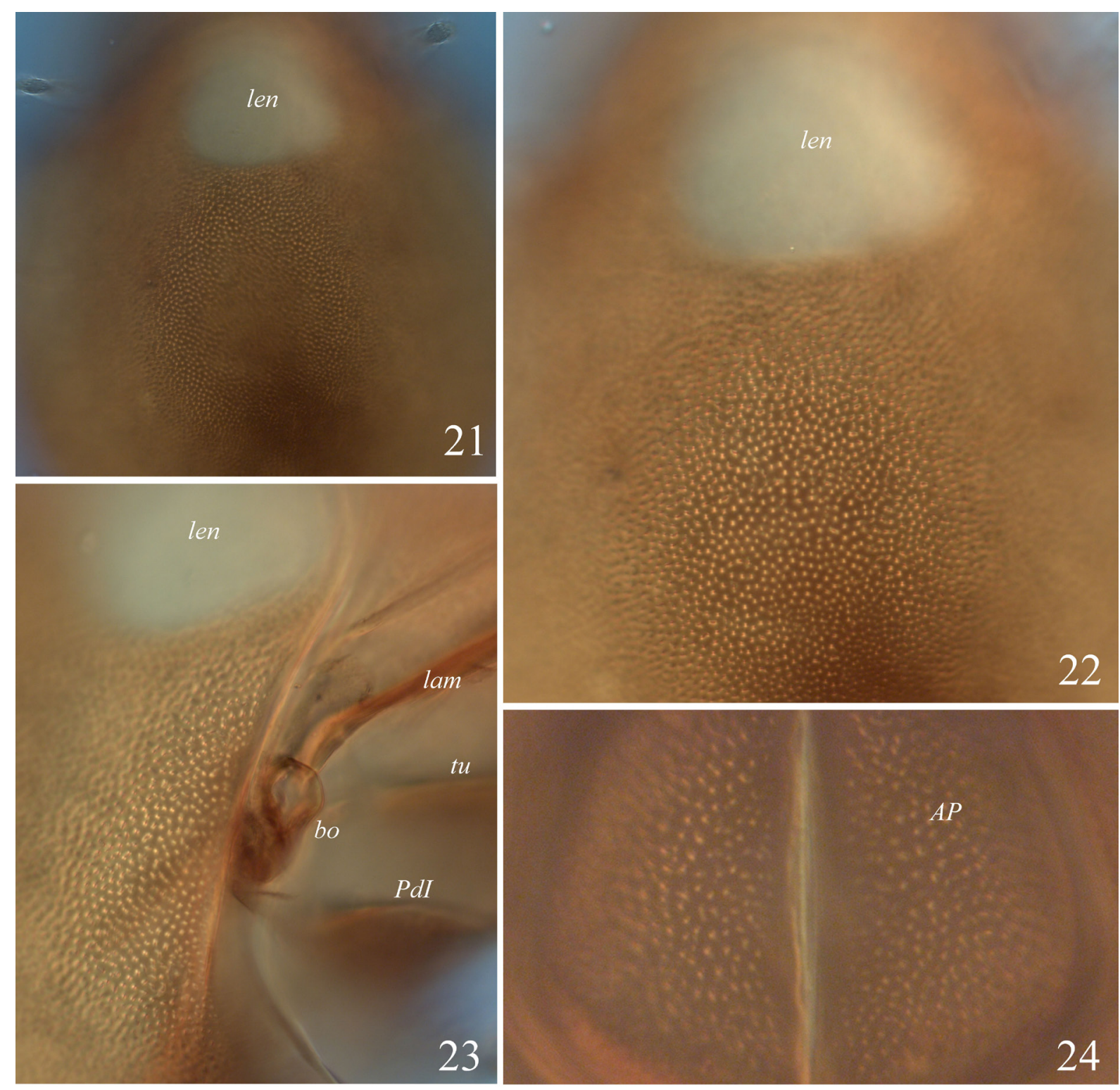

Figs. 21-24. Hypozetes andreii sp.n., adult, images: 21-23-heavily porose surface of notogaster; 24-heavily porose surface of anal plates.

Naval Hill, $29^{\circ} 05^{\prime} \mathrm{S}, 26^{\circ} 14^{\prime} \mathrm{E}$, in soil under bush vegetation, 13.X.2018 (collected by V.A. Khaustov, S.G. Ermilov, E.A. Hugo-Coetzee and A.A. Khaustov). Two paratypes (two males): South Africa, North West Province, near Klerksdorp, Faan Meintjes Nature Reserve, $26^{\circ} 42^{\prime} \mathrm{S} 26^{\circ} 42^{\prime} \mathrm{E}$, soil, 16.X.2018 (V.A. Khaustov and S.G. Ermilov).

Type deposition. The holotype and one paratype are deposited in the collection of the National Museum Bloemfontein, South Africa. Five paratypes are deposited in the collection of Tyumen State University Museum of Zoology, Tyumen, Russia. All preserved in ethanol with a drop of glycerol.
Etymology. The species is named after the late Dr. Andrei V. Bochkov (1968-2018), a distinguished acarologist from Saint Petersburg, Russia, for his extensive contributions to our knowledge of mites.

Remarks. Hypozetes andreii sp. n. is morphologically most similar to Hypozetes imitator Balogh, 1959 from the Ethiopian region and India (see Balogh 1959) in the presence of three pairs of adanal setae and comparatively long notogastral setae including $p_{1}-p_{3}$. We compared our specimens to specimens of $H$. imitator from the type series (Hungarian Natural History Museum, Hungary). The new species differs from the latter by the 


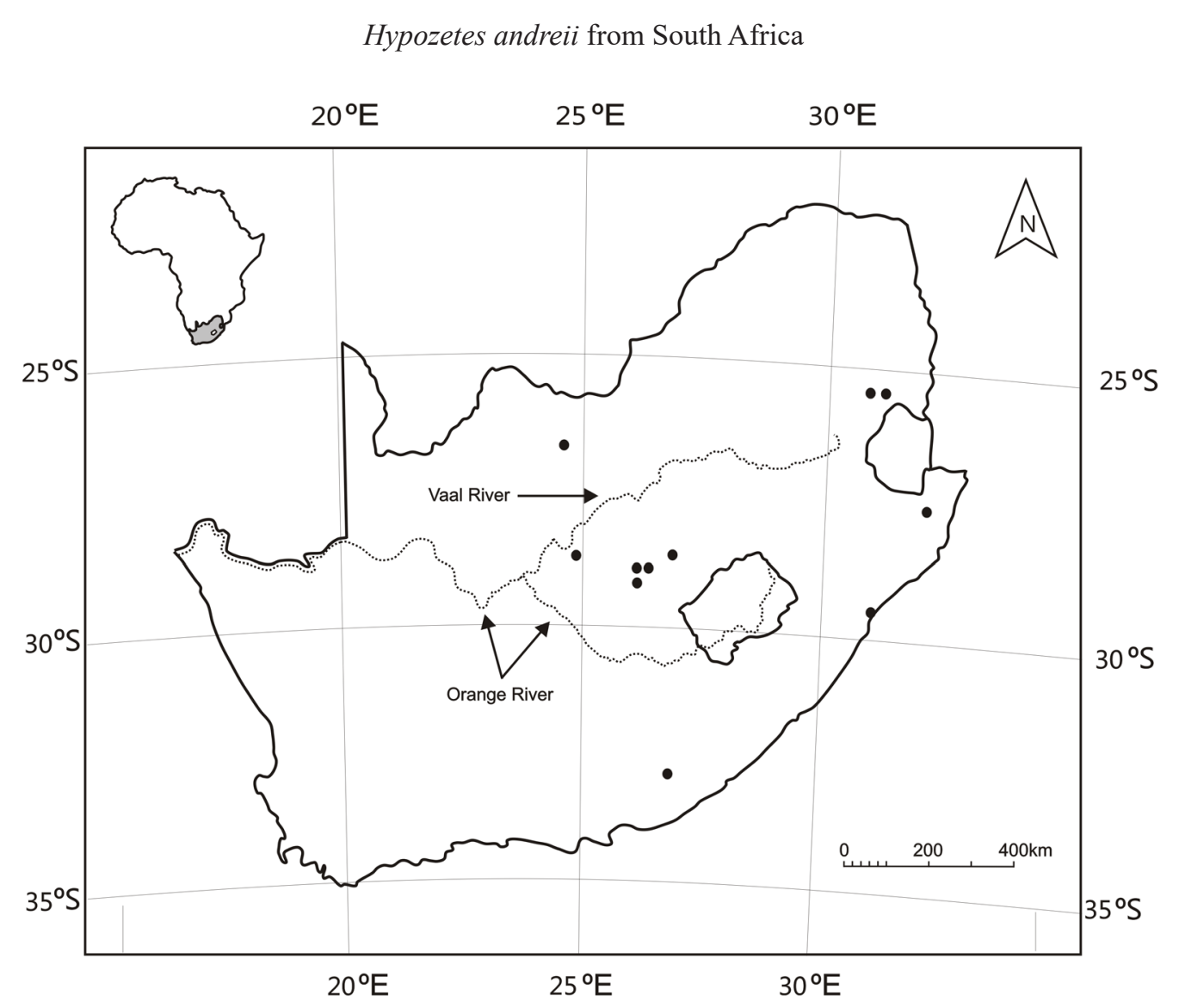

Fig. 25. Known distribution of Hypozetes andreii sp.n. in South Africa indicated by filled circles.

heavily and densely porose body surface (vs. smooth).

\section{DISTRIBUTION}

(Fig. 25)

The following distribution data of $H$. andreii sp. n. was obtained from the Acarology Collection of the National Museum Bloemfontein (NMB): NMB accession number 1537.6, Mkuze, KwaZulu Natal, $27^{\circ} 37^{\prime} \mathrm{S} 32^{\circ} 02^{\prime} \mathrm{E}$, from grass; NMB 3829.2 Mount Edgecombe, La Mercy, Kwa-Zulu Natal, $29^{\circ} 38^{\prime} \mathrm{S}, 31^{\circ} 08^{\prime} \mathrm{E}$, no habitat data; NMB 3615.14, Mbombela, Mpumalanga, $25^{\circ} 27^{\prime} \mathrm{S}$, $31^{\circ} 04^{\prime} \mathrm{E}$, underneath Kiaat and African beech trees;

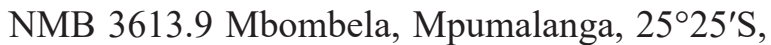
$30^{\circ} 55^{\prime} \mathrm{E}$, grass litter in a grassland; NMB 3663.3 Graspan near Kimberley, Northern Cape, $28^{\circ} 35^{\prime} \mathrm{S}$, $24^{\circ} 53^{\prime} \mathrm{E}$, soil and litter underneath a social weaver bird nest on a pole; NMB 3800.13 Alice, Eastern Cape, $32^{\circ} 47^{\prime} \mathrm{S}, 26^{\circ} 49^{\prime} \mathrm{E}$, grassland soil; NMB 3915.4, NMB 3916.1, Florisbad, Soutpan, Free State, $28^{\circ} 45^{\prime} \mathrm{S}, 26^{\circ} 03^{\prime} \mathrm{E}$, grassland vegetation; NMB 4433.1 Erfenis Dam Nature Reserve, near Theunissen, Free State, $28^{\circ} 30^{\prime} \mathrm{S} 26^{\circ} 46^{\prime} \mathrm{E}$, grass litter in grassland; NMB 4471.2, NMB 4473.2, NMB 4511.3 Glen Agricultural College, near
Bloemfontein, Free State, $28^{\circ} 56^{\prime} \mathrm{S}, 26^{\circ} 20^{\prime} \mathrm{E}$, soil and grass litter in a natural field of long grass.

In this study, the new species was sampled in Bloemfontein and near Klerksdorp (see "Material examined" section for details). The habitats, from which the specimens were sampled, were 'soil under bush vegetation' and 'soil', respectively, but the general areas were grassland dominated.

According to Behan-Pelletier (2001), $H y$ pozetes species, in general, occur in soils and sands associated with grasses and low-growing herbs. Our sampled habitats largely support this observation. Interestingly, $H$. andreii sp.n. was rarely encountered in samples, which may have been due to the sampling method. In particular, according to the observations by Behan-Pelletier (2001), Hypozetes species often move onto live grasses and low-growing plants. Since our samples were mostly taken from soil and litter and not from live grasses, a different sampling approach might produce more specimens of this genus.

\section{ACKNOWLEDGEMENTS}

We thank A.A. Gubin for SEM micrographs. The study was funded by the Russian Foundation for Basic Research (research project No 18-04-00096). 


\section{REFERENCES}

Balogh, J. 1959. Some oribatid mites from Eastern Africa (Acari: Oribatidae). Acta Zoologica Academiae Scientiarum Hungaricae, 5 (1-2): 13-32.

Balogh, J. and Balogh, P. 1992. The oribatid mite genera of the World. Vol. 1. Hungarian National Museum Press, Budapest, 263 pp.

Bayartogtokh, B., Ermilov, S.G., Hugo-Coetzee, E.A. and Khaustov, A.A. 2018. Contribution to the knowledge of the oribatid mite genus Licnodamaeus Grandjean, 1931 and synonymy of Licnodamaeolus Covarrubias, 1998 (Acari, Oribatida, Licnodamaeidae). Systematic and Applied Acarology, 23 (1): 42-60.

Behan-Pelletier, V.M. 2001. Phylogenetic relationships of Hypozetes (Acari: Tegoribatidae). In: R.B. Halliday, D.E. Walter, H.C. Proctor, R.A. Norton and M.J. Colloff (Eds.). Acarology: Proceedings of the $10^{\text {th }}$ International Congress. CSIRO Publishing, Melbourne, pp. 50-57.

Ermilov, S.G. and Hugo-Coetzee, E.A. 2019. New data on oribatid mites (Acari, Oribatida) of South Africa, with description of two new species of the family Oppiidae. Systematic and Applied Acarology, 24 (2), 287-302.

Ermilov, S.G., Hugo-Coetzee, E.A. and Khaustov, A.A. 2017. Oribatid mites (Acari, Oribatida) inhabiting nests of the termite Trinervitermes trinervoides (Sjöstedt) in the Franklin Game Reserve (Bloemfontein, South Africa), with description of a new species of the genus Ceratobates (Tegoribatidae). Systematic and Applied Acarology, 22 (10): 1715-1732.

Ermilov, S.G., Hugo-Coetzee, E.A. and Theron, P.D. 2018. To the knowledge of oribatid mites of the subgenus Galumna (Galumna) Heyden 1826 (Acari, Oribatida, Galumnidae) in South Africa, with a key to species known from the Ethiopian region. Zoologichesky Zhurnal, 97 (5): 515-527.

Ermilov, S.G., Hugo-Coetzee, E.A., Khaustov, A.A. and Theron, P.D. 2019. Oribatid mites (Acari, Oribatida) inhabiting termite nests in the Faan Meintjes Nature Reserve (South Africa). Systematic and Applied Acarology, 24 (9), 1783-1798.

Mahunka, S. 1987. Oribatids from Africa (Acari: Oribatida). V. Folia Entomologica Hungarica, 48: 105-128.

Niedbała, W., Hugo-Coetzee, E.A. and Ermilov, S.G. 2019. New Notophthiracarus species (Acarina, Oribatida, Phthiracaridae) and overview of the distribution of the genus in South Africa. Zootaxa, 4647 (1): 231-240.

Norton, R.A. 1977. A review of F. Grandjean's system of leg chaetotaxy in the Oribatei (Acari) and its application to the family Damaeidae. In: D.L. Dindal (Ed.). Biology of oribatid mites. SUNY College of Environmental Science and Forestry, Syracuse, pp. 33-61.

Norton, R.A. and Behan-Pelletier, V.M. 2009. Oribatida. In: G.W. Krantz and D.E. Walter (Eds.). A Manual of Acarology (TX). Texas University Press, Lubbock, ch. 15, pp. 430-564.

Subías, L.S. 2004. Listado sistemático, sinonímico y biogeográfico de los ácaros oribátidos (Acariformes: Oribatida) del mundo (excepto fósiles). Graellsia, 60 (número extraordinario): 3-305.

Subías, L.S. 2019. Listado sistemático, sinonímico y biogeográfico de los ácaros oribátidos (Acariformes: Oribatida) del mundo (excepto fósiles). 536 pp. Accessed in March 2019 at http://bba.bioucm.es/cont/docs/RO_1.pdf

Travé, J. and Vachon, M. 1975. François Grandjean. 1882-1975 (Notice biographique et bibliographique). Acarologia, 17 (1): 1-19.

Table 1

Leg setation and solenidia of Hypozetes andreii sp. n.

\begin{tabular}{|l|l|l|l|l|l|}
\hline Leg & $\boldsymbol{T} \boldsymbol{F e}$ & $\boldsymbol{G e}$ & $\boldsymbol{T i}$ & $\boldsymbol{T a}$ \\
\hline I & $v^{\prime}$ & $d,(l), b v^{\prime \prime}, v^{\prime}$ & $(l), v^{\prime}, \sigma$ & $(l),(v), \varphi_{1}, \varphi_{2}$ & $(f t),(t c),(i t),(p),(u),(a), s,(p v), v^{\prime},(p l), \varepsilon, \omega_{1}, \omega_{2}$ \\
\hline II & $v^{\prime}$ & $d,(l), b v^{\prime \prime}, v^{\prime}$, & $(l), v^{\prime}, \sigma$ & $(l),(v), \varphi$ & $(f t),(t c),(i t),(p),(u),(a), s,(p v), \omega_{1}, \omega_{2}$ \\
\hline III & $l^{\prime}, v^{\prime}$ & $d, l, e v^{\prime}$ & $l^{\prime}, \sigma$ & $l^{\prime},(v), \varphi$ & $(f t),(t c),(i t),(p),(u),(a), s,(p v)$ \\
\hline IV & $v^{\prime}$ & $d, e v^{\prime}$ & $d, l^{\prime}$ & $l^{\prime},(v), \varphi$ & $f t^{\prime},(t c),(p),(u),(a), s,(p v)$ \\
\hline
\end{tabular}

Note: Roman letters refer to normal setae, Greek letters to solenidia (except $\varepsilon$ - famulus), single prime (') marks setae on the anterior and double prime (") - setae on the posterior side of a given leg segment. Parentheses refer to a pair of setae. 